Ciência eNatura, Santa Maria, v. 37 Part 1 2015, p. 445-461

\title{
Planting arrangement, nitrogen resources and plant density on some vegetative characteristics of Melissa officinalis
}

\author{
Zahra Damavandi ${ }^{1}$, Saeed Sayfzadeh ${ }^{1}$ \\ ${ }^{1}$ Department of agronomy, Faculty of agriculture, Islamic Azad University, Takestan Branch, Takestan, \\ Iran
}

\begin{abstract}
In order to study the effect of nitrogen supply resources, planting arrangement and bush density on some vegetative characteristics in Melissa, an experiment was conducted as split-split- plot based on randomized complete blocks design with three replications in Takestan region in 2013. Planting arrangement were placed in two levels of diamond and square in main plots, nitrogen supply resources in three levels of chemical fertilizer, manure and vermicompost in sub plots and bush density in three levels of $30 \times 30 \mathrm{~cm}, 40 \times 40 \mathrm{~cm}$ and $50 \times 50 \mathrm{~cm}$ in sub sub plots, too. Traits such as bush height, stem diameter, number of leaves per bush, leaf and stem dry weight and lateral branches were Measured. The results indicated that greatest bush height, number of leaves and lateral branches and dry weight related to usage of nitrogen fertilizer. The greatest stem diameter, lateral branches and stem dry weight related to diamond arrangement. Also, the greatest bush height and leaf dry weight related to density of $30 \times 30 \mathrm{~cm}$, the greatest lateral branches, number of leaves per bush and stem dry weight related to $40 \times 40 \mathrm{~cm}$ density and the highest stem diameter related to $50 \times 50 \mathrm{~cm}$ density. The highest bush height, stem dry weight and number of leaves per bush belonged to square arrangement $\times$ chemical fertilizer $\times$ bush density of $30 \times 30 \mathrm{~cm}$ interaction treatment. Also, the greatest stem diameter and number of lateral branches belonged to diamond arrangement $\times$ manure fertilizer $\times$ bush density of $40 \times 40 \mathrm{~cm}$.
\end{abstract}

Key word: Melissa, Nitrogen supply resource, Planting arrangement, bush density and Vegetative characteristics 


\section{Introduction}

Melissa, is a stable, hyperbranched, bushy and perennial bush which grows in different areas of Iran, mostly in the form of a wild selfgrowing bush. Melissa grows rapidly, such that the bush is harvested in late May, before the appearance of flowers. This bush's flowering time begins from late summer and continues until winter (5). In indirect cultivation, seedlings are transferred to the main filed; there is a 50 to $60 \mathrm{~cm}$ distance from each row to the next. The proper distance between two bushes across each row is 30 to $40 \mathrm{~cm}$. 50 to 65 thousands seedlings are needed in every hectare. Late autumn is an appropriate time to bush the seeds directly in the main filed in which case a distance of $60 \mathrm{~cm}$ between cultivated rows is suitable. The seeding depth must be 0.5 to $1 \mathrm{~cm}$. In direct cultivation, 8 to $10 \mathrm{~kg}$ of seed in needed for every hectare (3). Nitrogen is a nutrient mineral which is required by most of the bushes. The main source of nitrogen for bushes is organic substances in the soil which are actually the remains of animals and bushes that are transferred to the soil naturally or as a result of human activity. In some cultivation systems, livestock manure or bush remains are added to the soil to compensate for a portion of the nitrogen consumed by the bush during the growing season (1). Vermicompost is composed of the mixture of worm waste along with decomposed organic substances and also the bodies of worms which is of great nutritional value for bushes. Livestock manure in agriculture is used for tissue and soil structure modification and also as a nutrition for bushes. This type of fertilizer contains varying amounts of nitrogen. Vermicompost is contain biologically active substances which act as growth regulators (2). Effect of bush density, nitrogen fertilizer qualities and effect between two factors on fresh and leaf dry weight were significant at 5\% level. But, nitrogen fertilizer shows no difference in statistical respect on its quality. Finally with density of the bush 160000 to 210000 bushes in every hectare and consuming $50 \mathrm{~kg}$ nitrogen fertilizer with function of leaf dry weight up to
3.54 tons in one hectare is recommended. Results of analysis of variance showed that bush height is affected by different levels of plant density and nitrogen quantity and interaction between them at $1 \%$ probability level (VakiliShahrbabaki, 2014). Hossein poor et al., (2011) reported significant effect of bush density on bush height, leaf number, biomass, seeds yield, harvest index of seed and essential oil. The means comparison indicated that the highest bush height and peduncle length were obtained from 50 bush. $m^{-2}$ of bush density. Also, the highest biomass yield (6319 kg. $\mathrm{ha}^{-1}$ ) and seed yield (1017 kg.ha ${ }^{-1}$ ) were obtained from 50 and 25 bush. $m^{-2}$ with 6 lit.ha $^{-1}$ of azotobacter application. Saeed-Nejad and RezvaniMoghaddam (2009) reported that vermicopost treatment indicated greatest bush height ratio to usage of manure and compost. Roa et al., (2003) showed that five ton of organic fertilizer increased leaf dry weight in comparison to control treatment (without consumption). Leaf dry yield increased significantly with increasing of distance from 30 to $45 \mathrm{~cm}$ in wide rows. Askari et al., (2012) showed that highest number of leaves per bush was obtained in density of 7 bush. $\mathrm{m}^{-2}$ and consumption of $50 \mathrm{~kg}$ nitrogen per hectare and maximum number of leaves was about 85 leaves per bush. Letchamo (1993), in an experiment conducted on Chamomile, came to the conclusion that increased levels of nitrogen fertilizer can lead to substantial improvements in bush height, stem function, dry and wet forage weight, and bush dry matter (10). Increasing of biomass under usage of organic fertilizer in Achillea millefolium reported by Scheffer and Koehler, (1993). Dadvand-Sarab et al., (2008), observed that increasing in nitrogen fertilizer, up to $100 \mathrm{~kg}$.ha1, leads to increased oil and dry matter performance per area unit. They also reported that this increase in the oil performance is in fact the result of increase in dry matter performance (4). In another experiment, it was shown that nitrogen leads to increase in bush height, the number of flower branches per bush, biomass performance in Nigella Sativa seed performance (6). The highest stem diameter was obtained at 
$45 \mathrm{~cm}$ row spacing (4). Investigations also showed that bush density leads to increase in bush height in anise, basil, fenugreek and German Chamomile. Animal manures improve physical properties of soil, such as better aeration, higher water holding capacity and better exchange of nutrients in the soil (7). A research was conducted by Farahmand et al., (2010) which aimed to investigate various levels of compost, vermicompost and animal manure on flowering and several vegetative traits of saffron. They reported that the main effect of type of fertilizer on vegetative traits is significant. Among all the studied characteristics, the highest average was obtained for manure (60 and 70 tons per hectare), however in some cases, there was no statistical difference between vermicompost with manure. Adjusting the distance between bushes is a powerful tool for controlling the competition between bushes of a species to produce the maximum amount of active ingredient (9). Therefore, the present study aim is to investigate the effect of planting arrangement, sources of nitrogen and bush density on some of the vegetative characteristics of Melissa.

\section{Materials and Methods}

In order to assess the effect of planting arrangement, supply resources of nitrogen and bush density on some of the vegetative characteristics of Melissa, an experiment as splitsplit plot was conducted based on randomized complete block design with three replications in Takestan region in 2013. Planting arrangement, sources of nitrogen and bush density were considered as the main-plot, sub-plot and subsub-plot, respectively. Planting arrangement was used on two levels: diamond and square. Nitrogen was taken from different resources of chemical, animal manure and vermicompost and bush density was assessed on three levels with $30 \times 30 \mathrm{~cm}, 40 \times 40 \mathrm{~cm}$ and $50 \times 50 \mathrm{~cm}$. All of the manure and vermicompost with half the nitrogen fertilizer were given to the soil as strip before transplanting. Also, the remaining nitrogen fertilizer were given after the first cutting in the corresponding experimental treatments. In order to prepare the field and create a favorable seed-bed for the cultivation of Melissa, first the soil was plowed to a depth of $20 \mathrm{~cm}$ using a moldboard plow. Then, in disk harrow was carried out in order to soften the soil and eliminate clods. Based on soil test results and fertilizer recommendation, values of phosphorus and potassium fertilizer were added to the soil with the last plow. The planting of seedlings were conducted at April 4, (2013) in rows by hand in 2 planning arrangement (diamond and square). Considering the texture and structure of the soil, the planting depth was chosen to be $5-7 \mathrm{~cm}$. Seedlings were planted in a planting line with equal spacing. The first irrigation was performed on March 25, (2013) before transplanting and in order to ensure the proper settle of seedlings, irrigation was repeated for 20 days every 5 days and thereafter until the start of summer every 7 days. After the first cutting, irrigation was carried out in the summer every 5 days. After seedlings settle, was done weedout. Transplanting was conducted on rows with a length of $4 \mathrm{~cm}$ and densities of $30 \times 30 \mathrm{~cm}, 40 \times$ $40 \mathrm{~cm}$ and $50 \times 50 \mathrm{~cm}$ according to the experimental treatments in all plots. The measured characteristics were bush height, stem diameter, number of leaves per bush, number of lateral branches and dry weight of leaves and stems. From each plot 10 bushes were selected randomly and average bush height, number of lateral branches per bush and dry weight of stem and leaf was recorded. bush height: measured by a ruler

Stem diameter: diameter of each stem in bush was measured by caliper.

Dry weight of stems: put each sample in oven at $75^{\circ} \mathrm{c}$ for $48 \mathrm{~h}$, then its weight obtained. 
Table1: Physicochemical properties of soil in experiment site.

\begin{tabular}{|c|c|c|c|c|c|c|c|c|c|c|c|c|c|c|c|}
\hline $\bar{\sigma}$ & $\mathbf{N}$ & 3 & ? & ${ }_{0}^{T}$ & $\sigma$ & $\frac{3}{6}$ & $\curvearrowright$ & $\pi$ & $\stackrel{\widehat{D}}{\stackrel{C}{C}}$ & 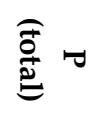 & $\mathbf{Z}$ & ○ & $\stackrel{\text { Th }}{\circ}$ & Ti & 葛 \\
\hline 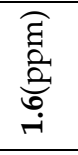 & 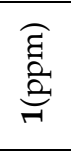 & ๕્ఃે & 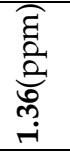 & 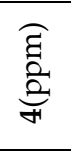 & 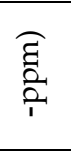 & 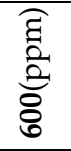 & ڤి & 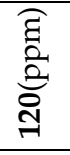 & 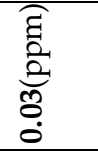 & 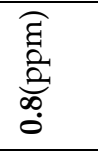 & $\begin{array}{l}\text { iั̀ } \\
\text { ลั }\end{array}$ & $\begin{array}{l}\stackrel{\circ}{\circ} \\
\stackrel{\infty}{0} \\
0\end{array}$ & 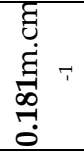 & 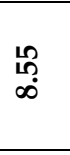 & $\overline{\tilde{B}}$ \\
\hline
\end{tabular}

The obtained data were analyzed using SAS statistical software and mean comparison were performed according to Duncan's Multiple Range Test at the 5\% probability level. Also, diagrams were plotted using Excel software.

\section{Results and Discussion}

\section{Bush Height}

Based on the data variance analysis with regard to bush height, it can be seen that the simple effect of resource of nitrogen supply and the dual interaction of planting arrangement $x$ resources of nitrogen, simple effect of bush density and bush density $\times$ resource of nitrogen were significant at $1 \%$ probability level and single effect of nitrogen resources and the triple interaction of planting arrangement $\times$ resource of nitrogen $\times$ bush density on bush height were not significant (table 2). According to the means comparison diagrams, the highest bush height were obtained from the following treatments: chemical fertilizer amount of $48.33 \mathrm{~cm}$ (diagram 1 ), density of $30 \times 30 \mathrm{~cm}$ (diagram 2), square planting arrangement $\times$ chemical fertilizer (diagram 3), chemical fertilizer $\times 30 \times$ $3 \mathrm{~cm}$ density amount of $52.67 \mathrm{~cm}$ (diagram 4 ). Hossein poor et al., (2011) montioned significant effect of bush density on bush height. Also, Saeed-Nejad and Rezvani -Moghaddam (2009) reported that vermicompost treatment indicated greatest bush height ratio to using manure and compost. Increasing of nitrogen of vermicompost caused bush height ratio to using manure and compost. Increasing of nitrogen of vermicompost caused bush height increased. The main reason for the increase in bush height in dense cultivation is the competition for access to light.

Table 2: Analysis of variance (MS) for studied traits

\begin{tabular}{lccc}
\hline Source of variation & d.f & bush height & stem diameter \\
\hline Replication(r) & 2 & 2.09 & 0.0006 \\
Planting arrangement(A) & 1 & $2.24^{\mathrm{ns}}$ & $0.05^{* *}$ \\
Main plot error & 2 & 0.35 & 0.00002 \\
N supply resources(N) & 2 & $31.02^{* *}$ & $0.00027^{\mathrm{ns}}$ \\
$\mathrm{N} \times \mathrm{A}$ & 2 & $32.46^{* *}$ & $0.004^{* *}$ \\
Sub plot error & 8 & 1.8 & 0.0002 \\
Bush density(D) & 2 & $318.57^{* *}$ & $0.14^{* *}$ \\
A $\times \mathrm{D}$ & 2 & $21.46^{\mathrm{ns}}$ & $0.02^{* *}$ \\
$\mathrm{~N} \times \mathrm{D}$ & 4 & $9.07^{* *}$ & $0.001^{* *}$ \\
A $\times \mathrm{N} \times \mathrm{D}$ & 4 & $9.68^{\mathrm{ns}}$ & $0.005^{\mathrm{ns}}$ \\
Sub-sub plot error & 24 & 0.45 & 0.00005 \\
\hline C.V $(\%)$ & \multicolumn{3}{c}{1.46} \\
\hline
\end{tabular}

ns and ${ }^{* *}$ non significant and significant at probability level of $5 \%$ and $1 \%$, respectively 
Table 3: Analysis of variance (MS) for number of lateral branches

\begin{tabular}{lcc}
\hline Source of variation & d.f & number of lateral branches \\
\hline Replication(r) & 2 & 1.80 \\
Planting arrangement(A) & 1 & $450.67^{* *}$ \\
Main plot error & 2 & 1.72 \\
N supply resources(N) & 2 & $1.24 \mathrm{~ns}$ \\
$\mathrm{~N} \times \mathrm{A}$ & 2 & $58.72^{* *}$ \\
Sub plot error & 8 & 1.26 \\
Bush density(D) & 2 & $253.02^{* *}$ \\
$\mathrm{~A} \times \mathrm{D}$ & 2 & $16.17^{* *}$ \\
$\mathrm{~N} \times \mathrm{D}$ & 4 & $8.63^{* *}$ \\
$\mathrm{~A} \times \mathrm{N} \times \mathrm{D}$ & 4 & $3.06^{\mathrm{ns}}$ \\
Sub-sub plot error & 24 & 0.68 \\
\hline C.V $(\%)$ & & 1.76 \\
\hline
\end{tabular}
ns and ${ }^{* *}$ non significant and significant at probability level of $5 \%$ and $1 \%$, respectively

Table 4: Analysis of variance (MS) for number of leaves per bush

\begin{tabular}{lcc}
\hline Source of variation & d.f & number of leaves per bush \\
\hline Replication(r) & 2 & 4201.06 \\
Planting arrangement(A) & 1 & $1330.07 \mathrm{~ns}$ \\
Main plot error & 2 & 633.8 \\
$\mathrm{~N}$ supply resources(N) & 2 & $390038.39^{* *}$ \\
$\mathrm{~N} \times \mathrm{A}$ & 2 & $1035325.02^{* *}$ \\
Sub plot error & 8 & 1170.84 \\
Bush density(D) & 2 & $270626.06^{* *}$ \\
$\mathrm{~A} \times \mathrm{D}$ & 2 & $181111.57^{* *}$ \\
$\mathrm{~N} \times \mathrm{D}$ & 4 & $1131519.94^{* *}$ \\
A $\times \mathrm{N} \times \mathrm{D}$ & 4 & $644739.52^{\mathrm{ns}}$ \\
Sub-sub plot error & 24 & 1750.62 \\
\hline C.V(\%) & & 4.68 \\
\hline
\end{tabular}

ns and ${ }^{* *}$ non significant and significant at probability level of $5 \%$ and $1 \%$, respectively

Table 5: Analysis of variance (MS) for leaf dry weight and stem dry weight

\begin{tabular}{lccc}
\hline Source of variation & d.f & leaf dry weight & stem dry weight \\
\hline Replication(r) & 2 & 6.21 & 0.95 \\
Planting arrangement(A) & 1 & $42.84^{\mathrm{ns}}$ & $0.39 \mathrm{~ns}$ \\
Main plot error & 2 & 0.08 & 0.67 \\
$\mathrm{~N}$ supply resources(N) & 2 & $231.3^{\mathrm{ns}}$ & $84.23^{* *}$ \\
$\mathrm{~N} \times \mathrm{A}$ & 2 & $189.62^{\mathrm{ns}}$ & $22.53^{* *}$ \\
Sub plot error & 8 & 0.73 & 0.72 \\
Bush density(D) & 2 & $702.53^{* *}$ & $225.89^{* *}$ \\
A $\times \mathrm{D}$ & 2 & $25.04^{* *}$ & $4.56^{* *}$ \\
$\mathrm{~N} \times \mathrm{D}$ & 4 & $187.08^{* *}$ & $6.1^{* *}$ \\
A $\times \mathrm{N} \times \mathrm{D}$ & 4 & $117.83^{\mathrm{ns}}$ & $16.29^{\mathrm{ns}}$ \\
Sub-sub plot error & 24 & 1.88 & 0.28 \\
\hline C.V $(\%)$ & & & 5.39 \\
\hline
\end{tabular}


ns and ${ }^{* *}$ non significant and significant at probability level of $5 \%$ and $1 \%$, respectively

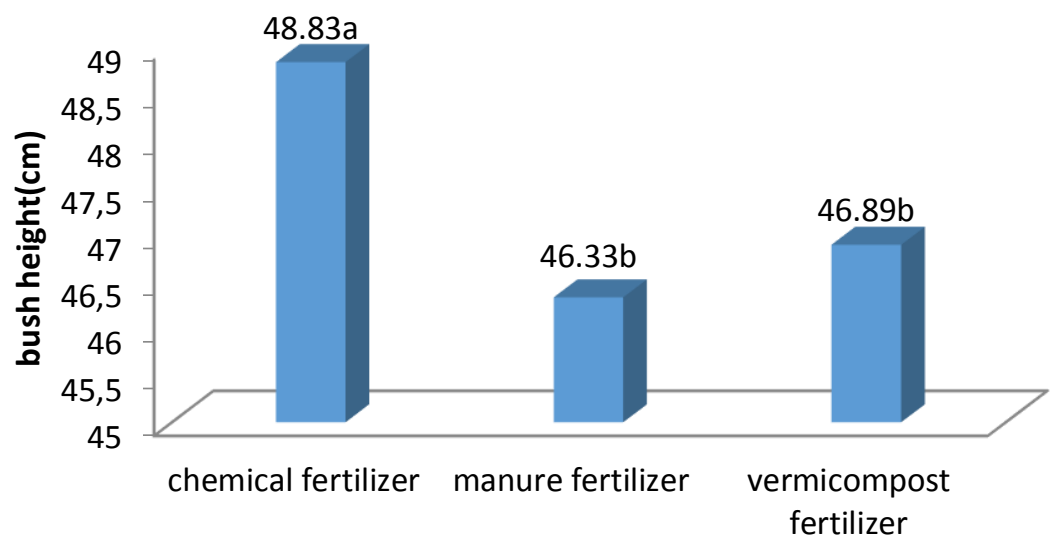

N supply resources

Diagram 1. Comparing the means of nitrogen resources on bush height

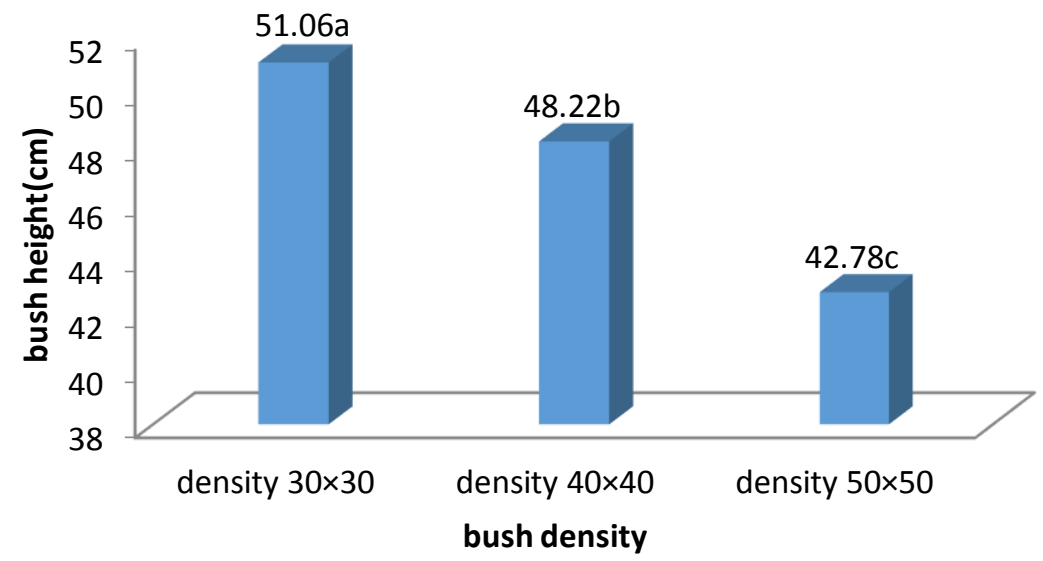

Diagram 2. Comparing the means of bush density on bush height

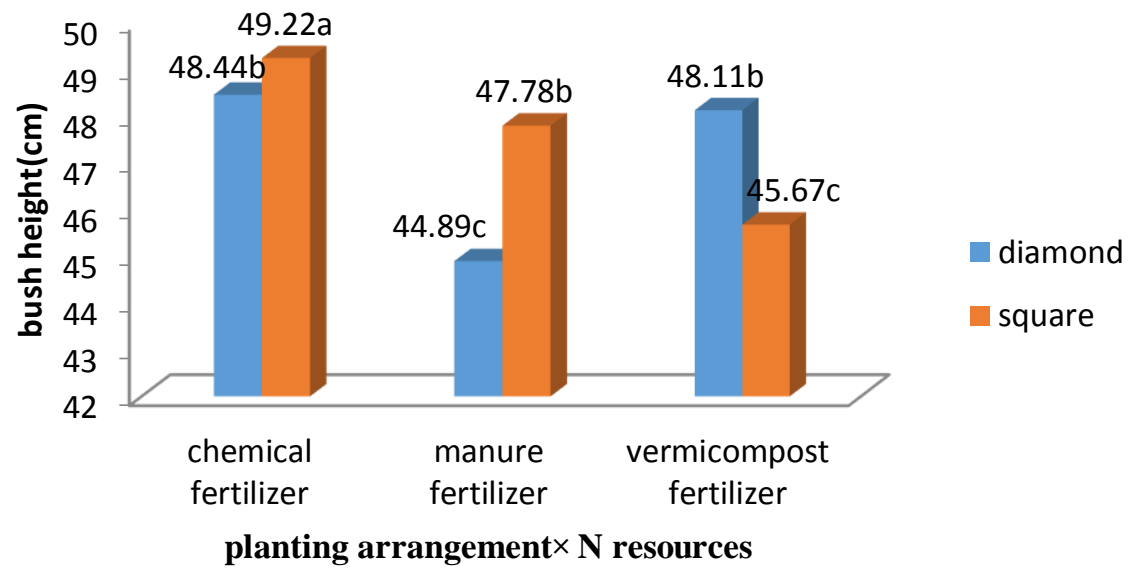

Diagram 3. Comparing the means of planting arrangement $\times N$ resources on bush height 


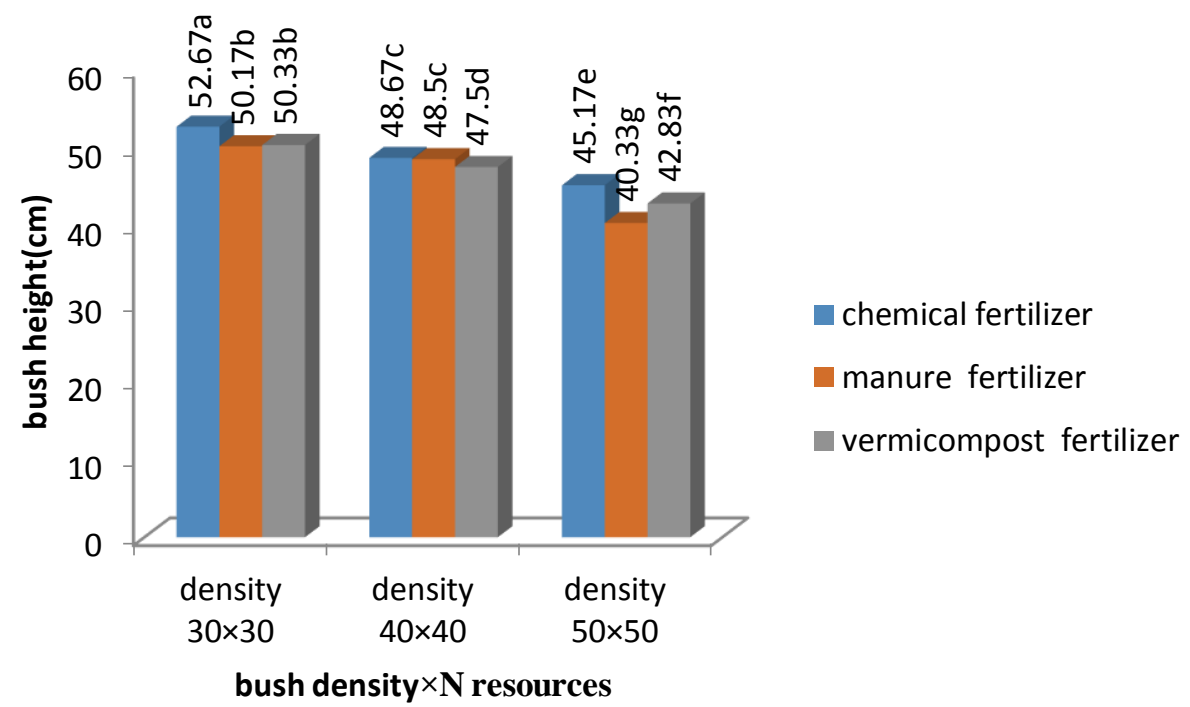

Diagram 4. Comparing the means of nitrogen resources $\times$ bush density on bush height

\section{Stem Diameter}

Based on the data variance analysis with regard to stem diameter, it can be seen that the simple effect of source of nitrogen supply is not significant and planting arrangement and bush density and the dual interaction of bush density $\times$ planning arrangement, planting arrangement $\times$ source of nitrogen and source of nitrogen $x$ bush density were significant at probability level $1 \%$ and single effect of nitrogen resources and the triple interaction of planting arrangement $x$ source of nitrogen $\times$ bush density on stem diameter were not significant. (table 2). The highest amount of stem diameter were obtained from the following treatments: square planting arrangement $(0.52 \mathrm{~cm})$ (diagram 5$)$, density of $50 \times 50 \mathrm{~cm} \quad(0.56 \mathrm{~cm}) \quad($ diagram 6), diamond planting arrangement $\times 50 \times$ $50 \mathrm{~cm}$ density $(0.6 \mathrm{~cm})$ (diagram 7), manure fertilizer $\times$ diamond planting arrangement and using vermicompost $\times$ diamond planting arrangement (diagram 8) and manure fertilizer $\times 50 \times 50 \mathrm{~cm}$ density amount of 0.58 (diagram 10).

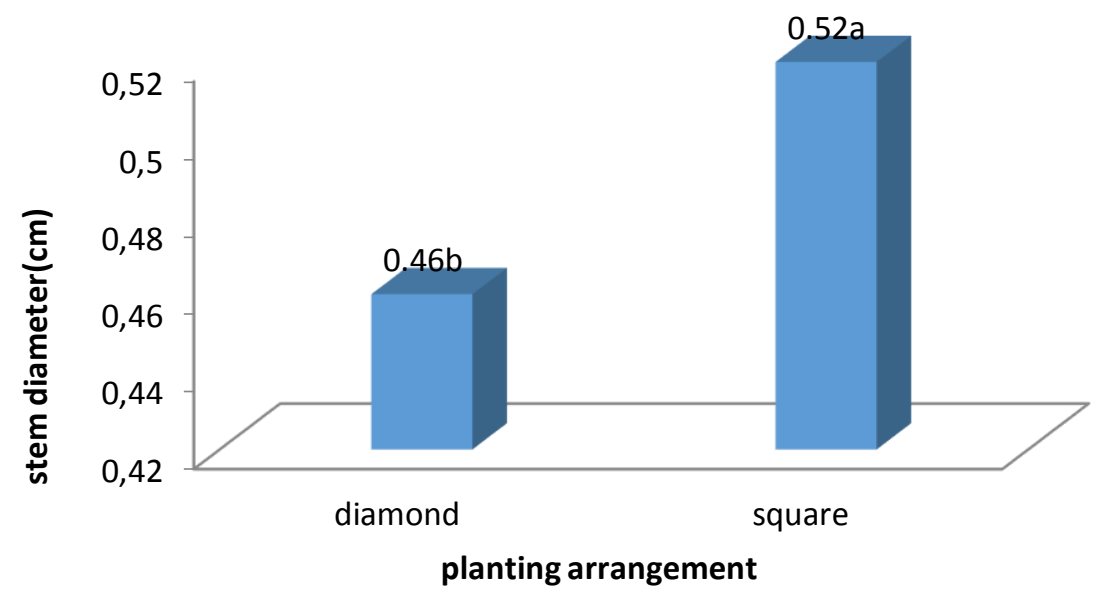

Diagram 5. Comparing the means of planting arrangement on stem diameter 


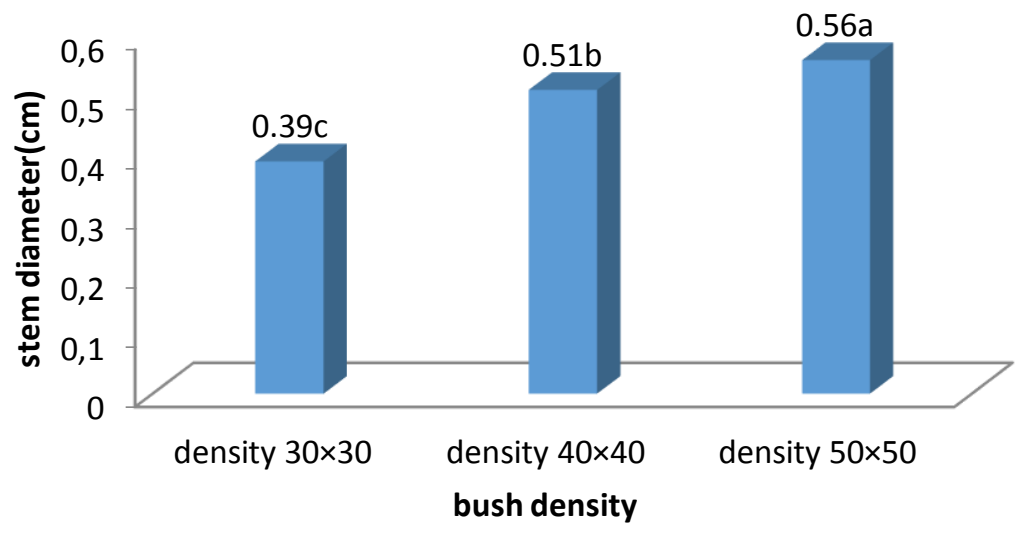

Diagram 6. Comparing the means of bush density on stem diameter

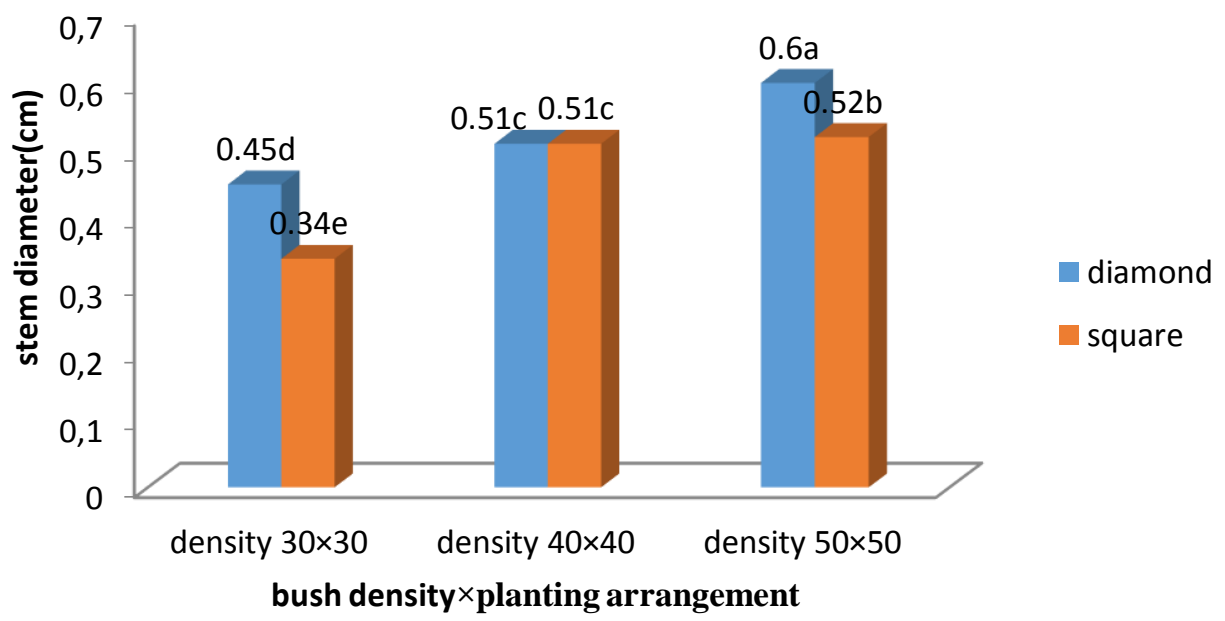

Diagram 7. Comparing the means of planting arrangement $\times$ bush density on stem diameter

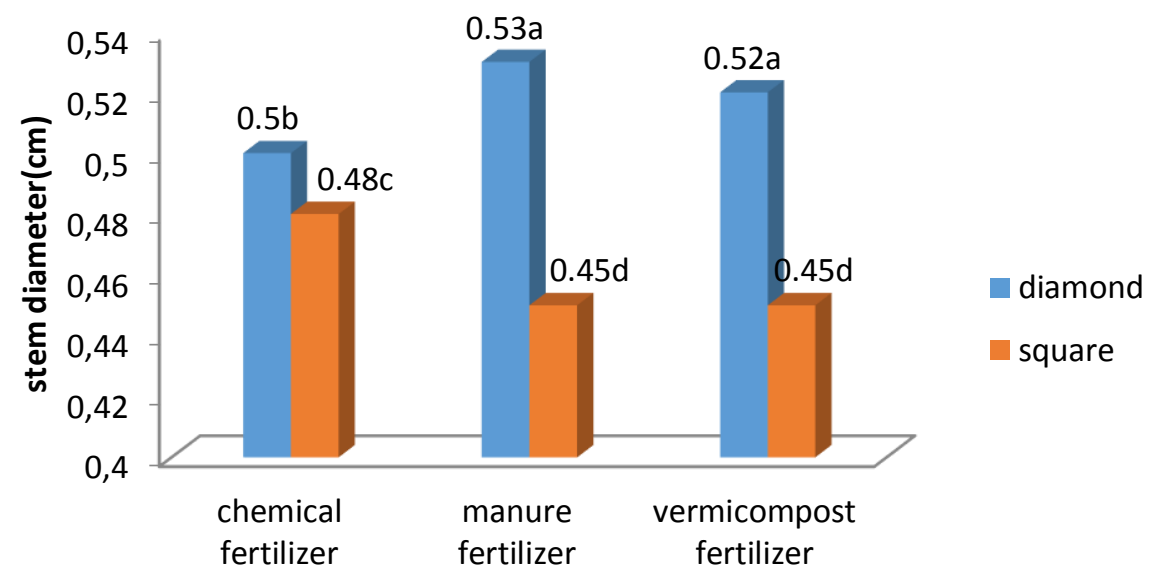

$N$ supply resources $\times$ planting arrangement

Diagram 8. Comparing the means of nitrogen fertilizer $\times$ bush density on stem diameter 


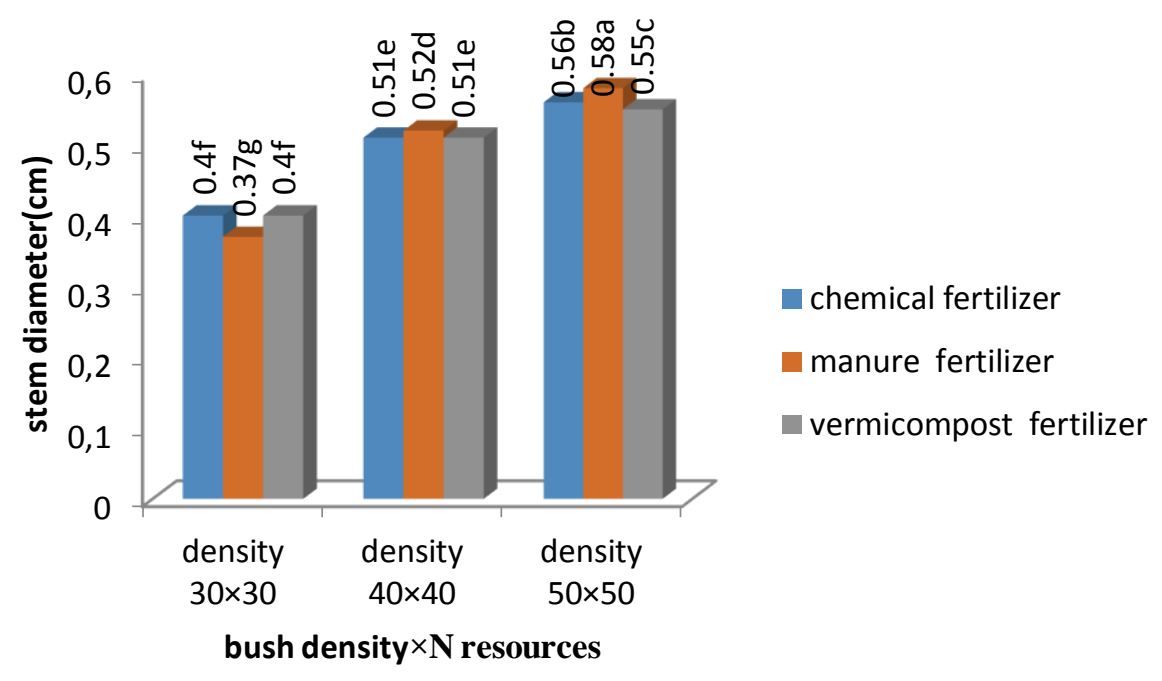

Diagram 9. Comparing the means of planting pattern $\times$ nitrogen resources on stem diameter

\section{Number of Lateral Branches}

Based on the data variance analysis with regard to number of lateral branches, it can be seen that the simple effect of source of nitrogen is non-significant, and planting arrangement and bush density and the dual interaction of planting arrangement $\times$ source of nitrogen, bush density $\times$ planning arrangement, source of nitrogen $\times$ bush density were significant at the level of $1 \%$. Also, the triple interaction of planting arrangement $\times$ source of nitrogen $\times$ bush density on lateral branches was not significant at the level of $1 \%$ (table 3). The highest amount of lateral branches were obtained from the following treatments: square planting arrangement (49.48 number) (diagram 10), bush density of $40 \times 40 \mathrm{~cm}$ (diagram 11), diamond planting arrangement $\times$ density of $40 \times 40 \mathrm{~cm}$ (diagram 12), diamond planting arrangement $\times$ manure (diagram 13), and manure $\times 40 \times 40 \mathrm{~cm}$ density (diagram 14). Molafilabi et al., (2009) was shown that nitrogen lead to increase number of flower branches per bush in nigella sativa.

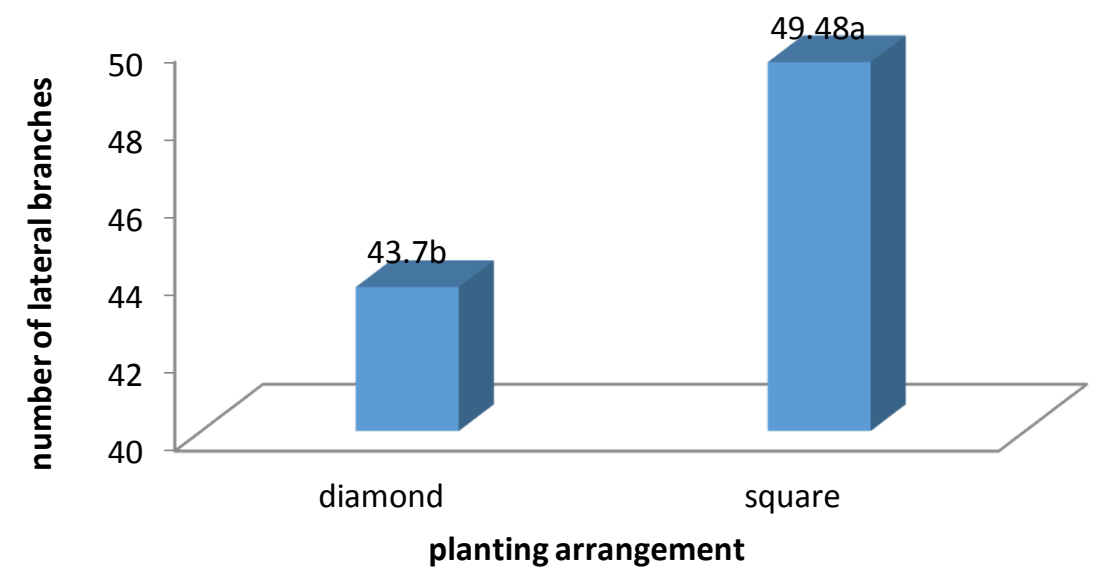

Diagram 10. Comparing the means of planting arrangement on lateral branches 


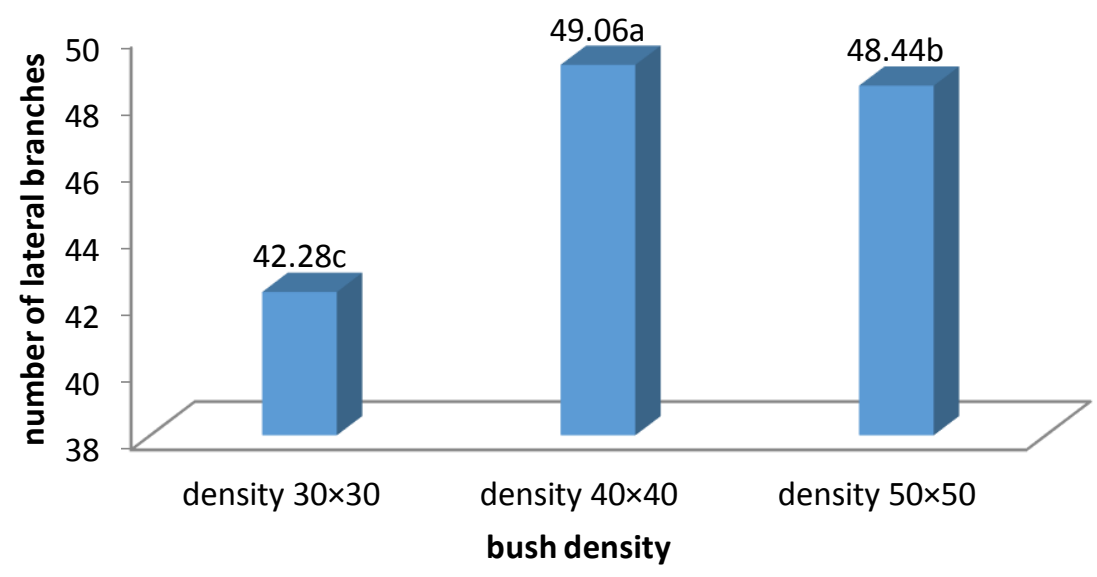

Diagram 11. Comparing the means of bush density on lateral branches

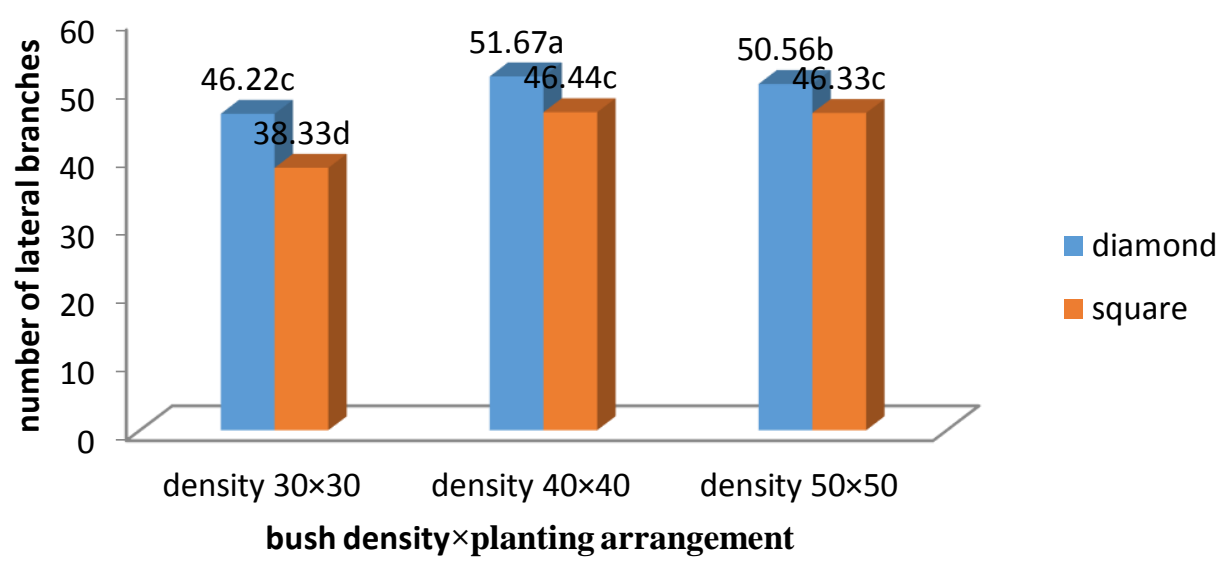

Diagram 12. Comparing the means of planting arrangement $\times$ bush density on lateral branches

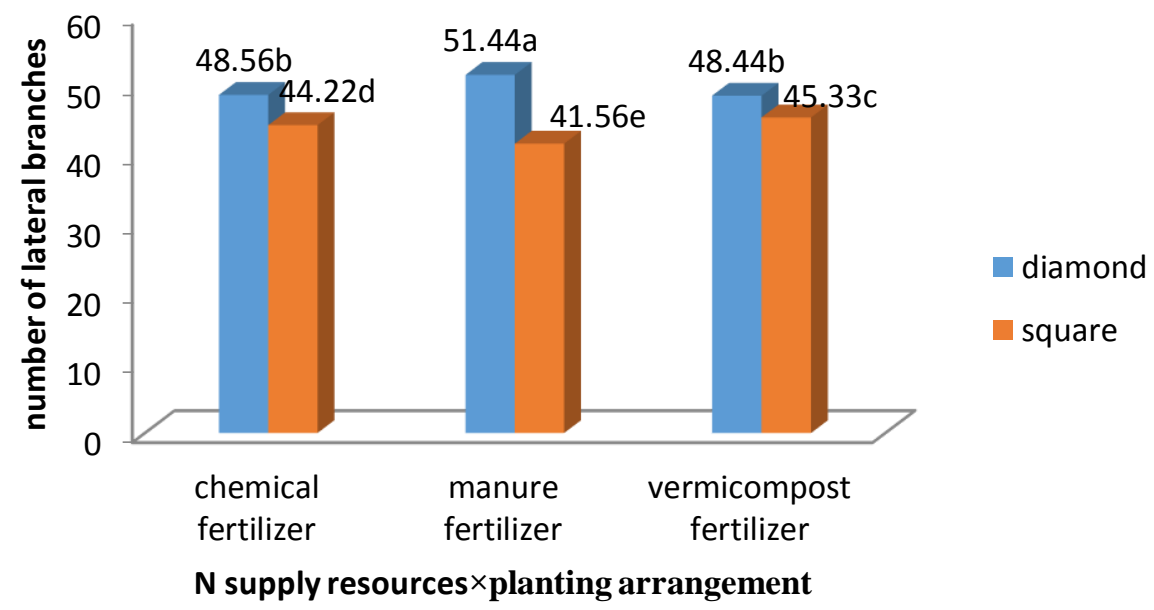

Diagram 13. Comparing the means of planting arrangement $\times$ nitrogen resources on lateral branches 


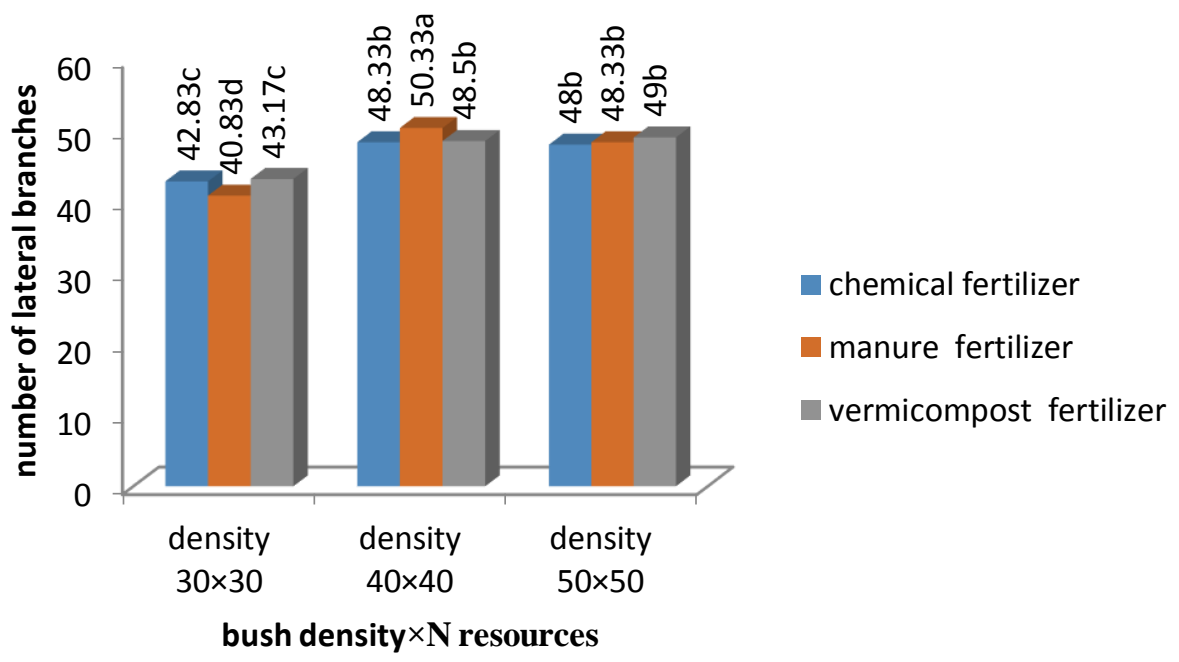

Diagram 14. Comparing the means of nitrogen resources $\times$ bush density on lateral branches

\section{Number of leaves per bush}

Based on the data variance analysis with regard to number of leaves, it can be seen that the simple effect of source of nitrogen and bush density and the dual interaction of planting arrangement $\times$ source of nitrogen, bush density $x$ planting arrangement, source of nitrogen $x$ bush density were significant at probability level $1 \%$ and single effect of planting arrangement and triple interaction of planting arrangement $x$ source of nitrogen $\times$ bush density on the number of leaves per bush were not significant on the number of leaves per plant. (table 4). The greatest number of leaves per bush was obtained from the following treatments: density of $40 \times 40 \mathrm{~cm}$ (diagram 15), chemical fertilizer (diagram 16), square planting arrangement $\times$ chemical fertilizer (diagram 17), diamond planting arrangement $\times$ density of $40 \times$ $40 \mathrm{~cm}$ (diagram 18)chemical fertilizer $\times 30 \times$ $30 \mathrm{~cm}$ density (diagram 19). Askari et al., (2012) and Hossein Poor (2011) reported significant effect bush density on number of leaves.

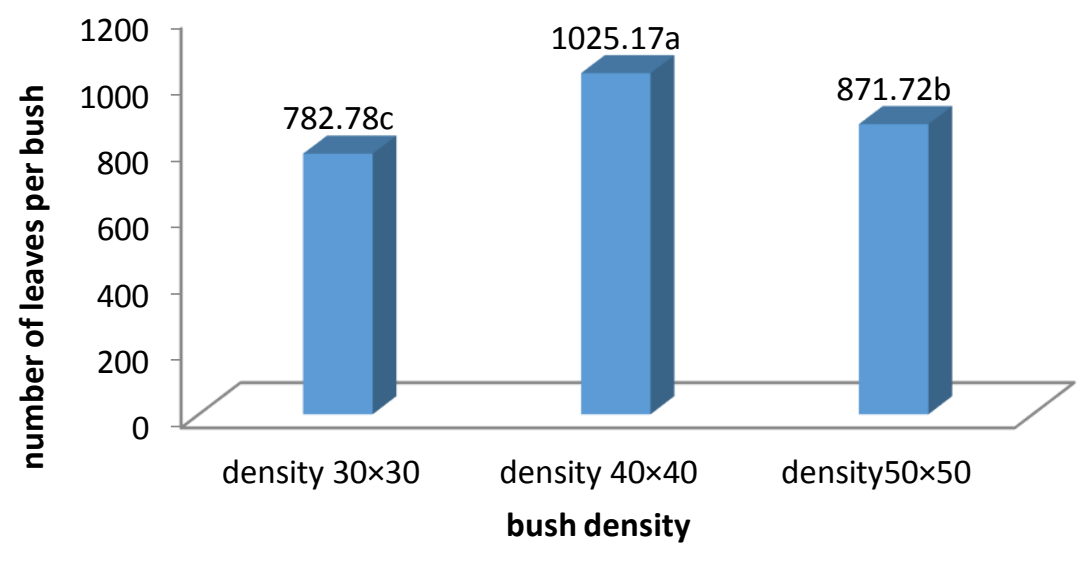

Diagram 15. Comparing the means of bush density on number of leaves 


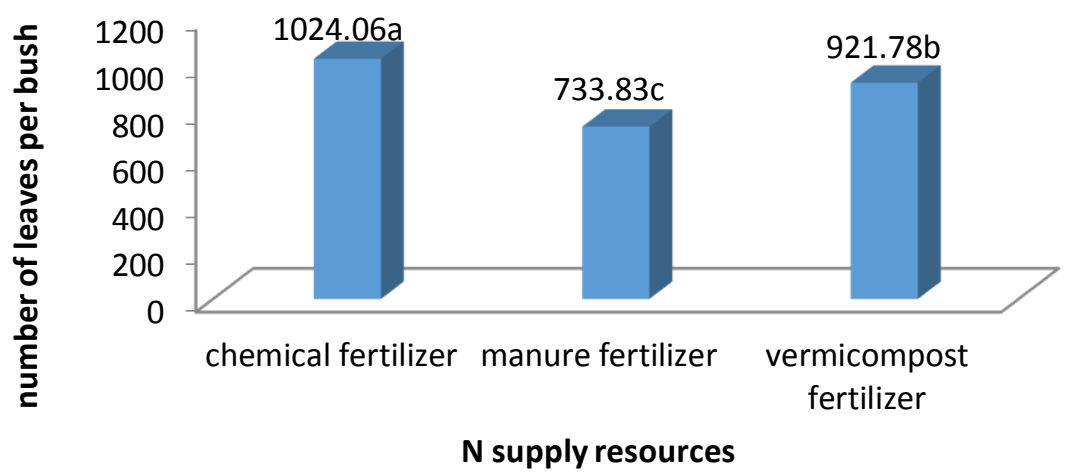

Diagram 16. Comparing the means of nitrogen fertilizer on number of leaves

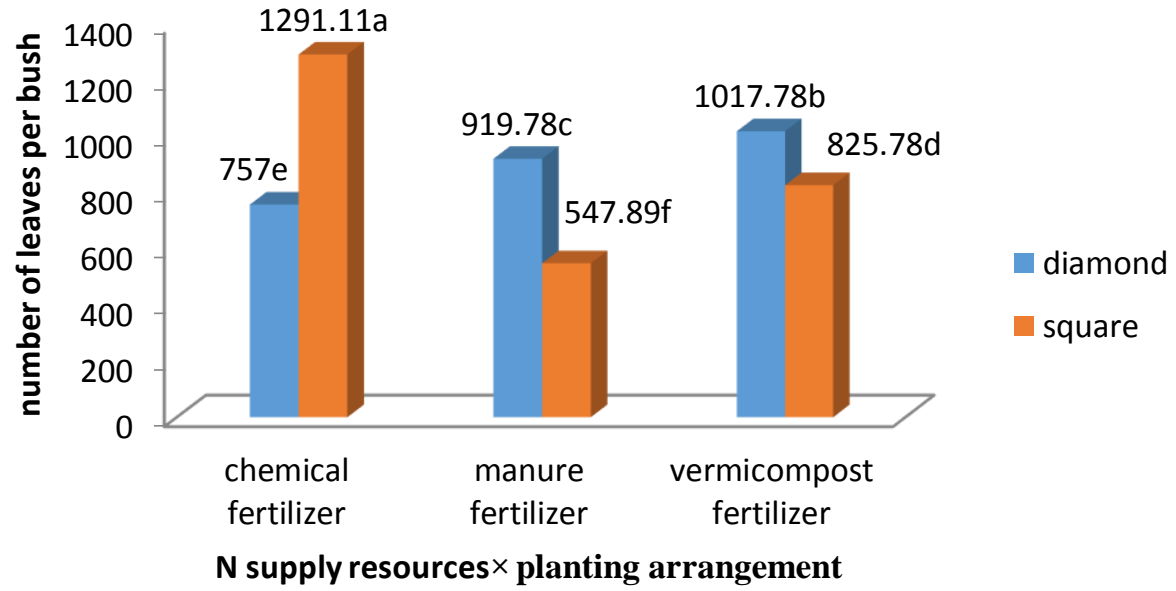

Diagram 17. Comparing the means of planting arrangement $\times$ nitrogen resources on number of leaves

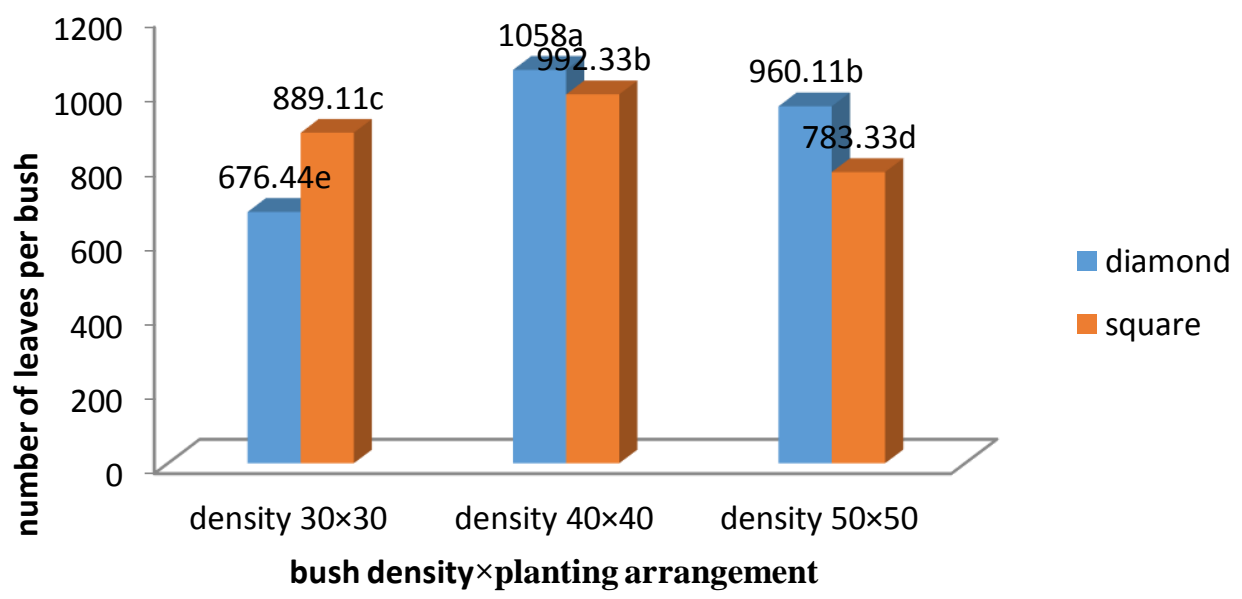

Diagram 18. Comparing the means of planting arrangement $\times$ bush density on number of leaves 


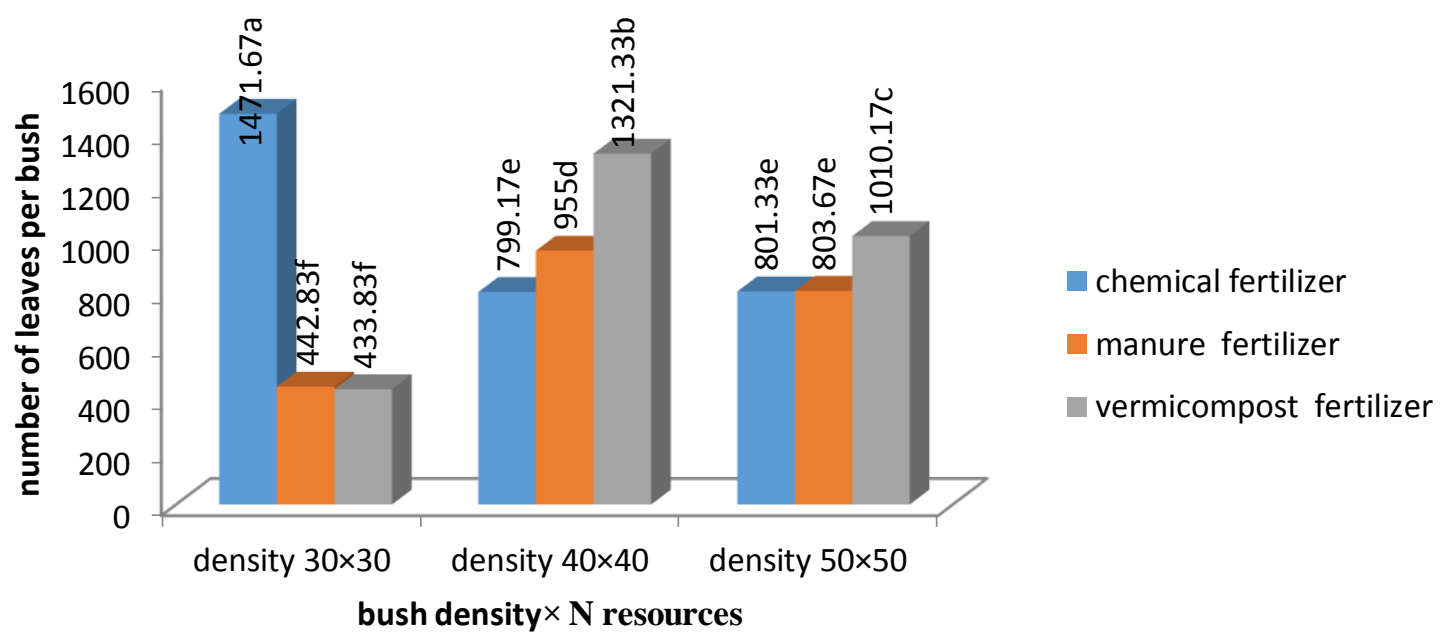

Diagram 19. Comparing the means of nitrogen resources $\times$ bush density on number of leaves

\section{Leaf Dry Weight}

Based on the data variance analysis with regard to leaf dry weight, it can be seen that the simple effect of bush density, the dual interaction of planting arrangement $\times$ bush density and source of nitrogen $\times$ bush density on the leaf dry weight were significant at the level of $1 \%$ and other treatments were not significant on the leaf dry weight (table 5). The highest amount of leaf dry weight was obtained from the following treatments: density of $40 \times$ $40 \mathrm{~cm}$ (diagram 20), diamond planting arrangement $\times$ density of $40 \times 40 \mathrm{~cm}$ (diagram
21), chemical fertilizer $\times$ bush density of $40 \times$ $40 \mathrm{~cm}$ (diagram 22). Dadvand-Sarab et al., (2008) observed that increasing in nitrogen fertilizer leads to increased dry matter performance per area unit. In according with previous reports (Vakili-Shahrbabaki, 2014), bush density and nitrogen fertilizer and effect between two factor were significant on leaf dry weight that is similar to this results. Roa et al., (2003) showed that using five tone per hectare organic fertilizer increased leaf dry weight in comparison to control treatment. Leaf dry weight increased significantly with increasing of distance from $30 \mathrm{~cm}$ to $45 \mathrm{~cm}$ in wide row (Roa et al., 2003).

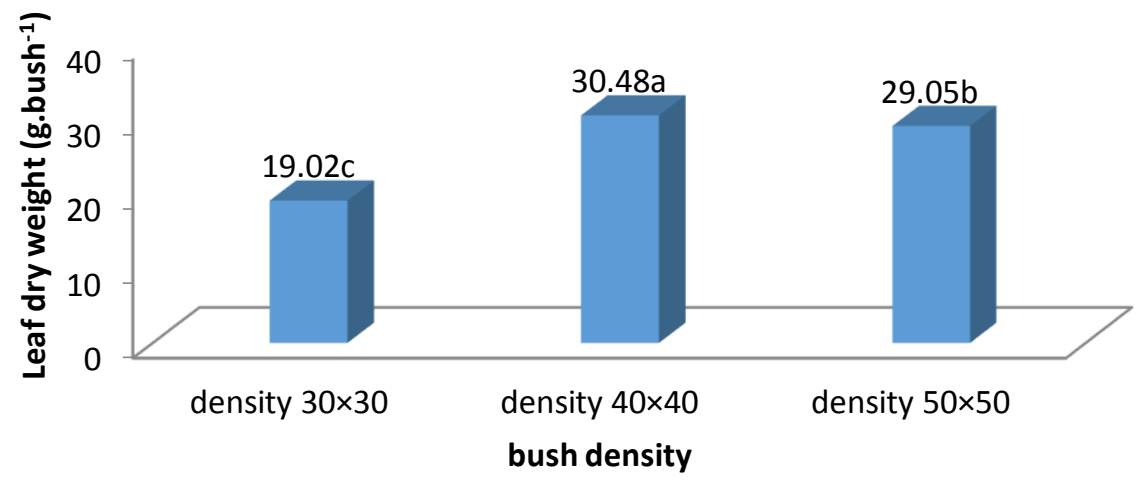

Diagram 20. Comparing the means of bush density on leaf dry weight 


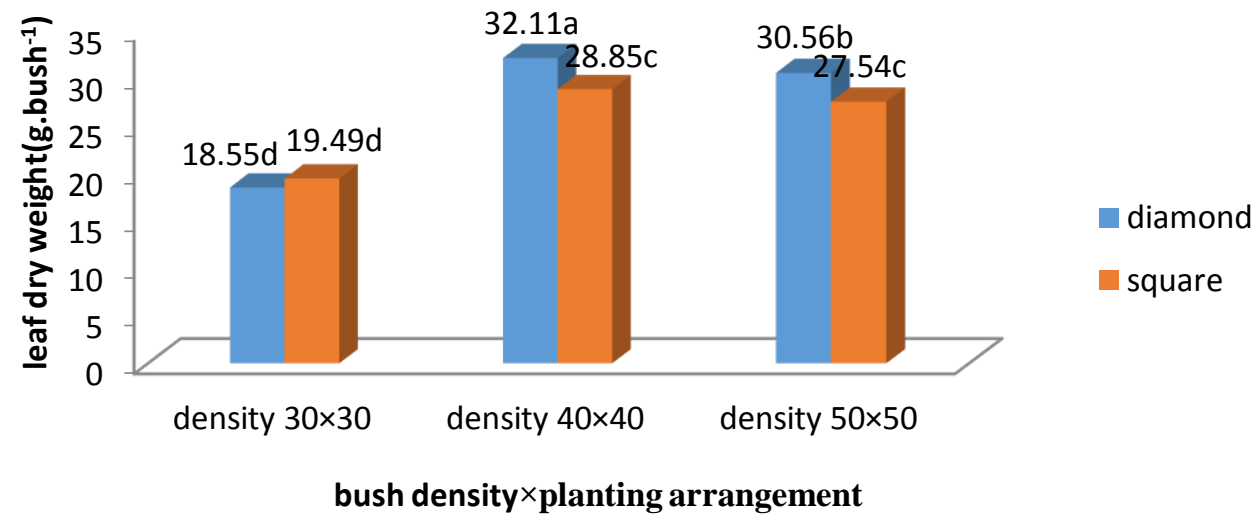

Diagram 21. Comparing the means of planting arrangement $\times$ bush density on leaf dry weight

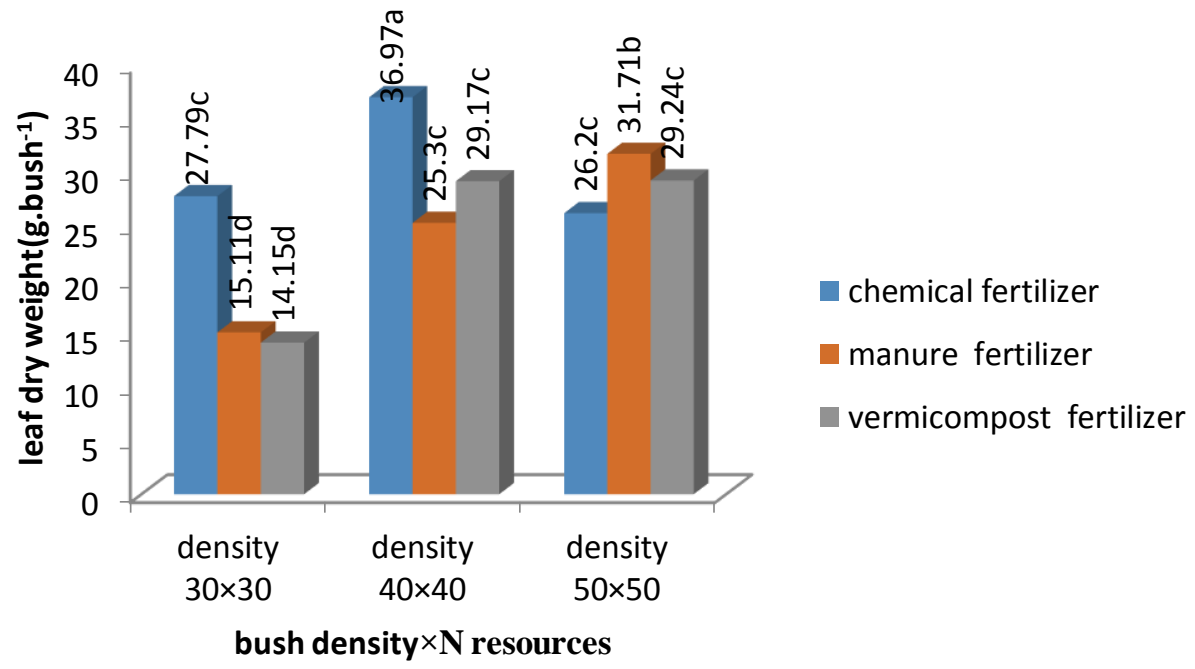

Diagram 22. Comparing the means of nitrogen resources $\times$ bush density on leaf dry weight

\section{Stem Dry Weight}

The simple effect of planting arrangement, source of nitrogen and bush density and the dual interaction of planting arrangement $x$ source of nitrogen and source of nitrogen $x$ bush density were significant on the stem dry weight at probability level $1 \%$ and the dual interaction bush density $\times$ planting arrangement and triple interaction of planting arrangement $x$ source of nitrogen $x$ bush density on the stem dry weight were not significant (table 5). The greatest stem dry weight per unit area was obtained from the following treatments: diamond planting arrangement (diagram 23), chemical fertilizer (diagram 24), density of $40 \times$ $40 \mathrm{~cm}$ (diagram 25), square planting arrangement $\times$ chemical fertilizer (diagram 26), chemical fertilizer $\times$ density of $40 \times 40 \mathrm{~cm}$ (diagram 27). Molafilabi et al., (2009) indicated that increasing of nitrogen fertilizer increased stem dry weight and biomass. Farhamand et al., (2010) reported that the main effect of type of fertilizer on vegetative traits was significant and the greatest average was obtained for animal manure ratio to vermicompost and compost. 


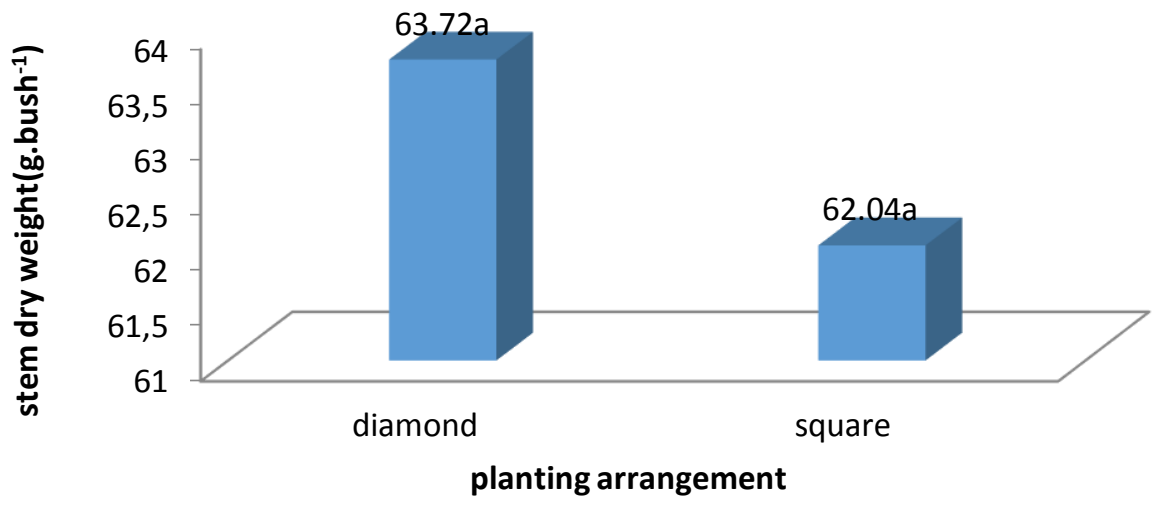

Diagram 23. Comparing the means of planting arrangement on stem dry weight

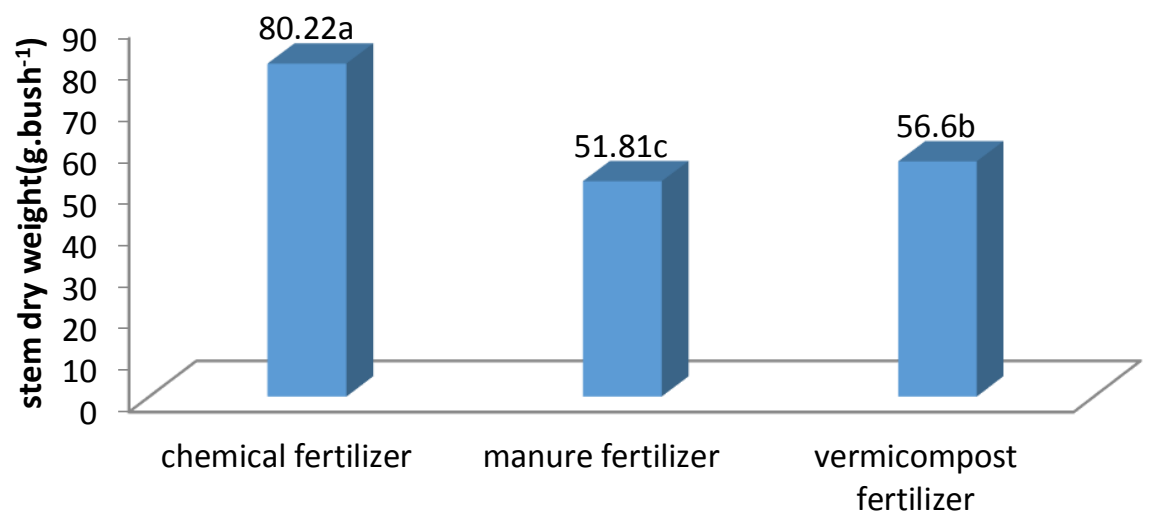

N supply resources

Diagram 24. Comparing the means of nitrogen fertilizer on stem dry weight

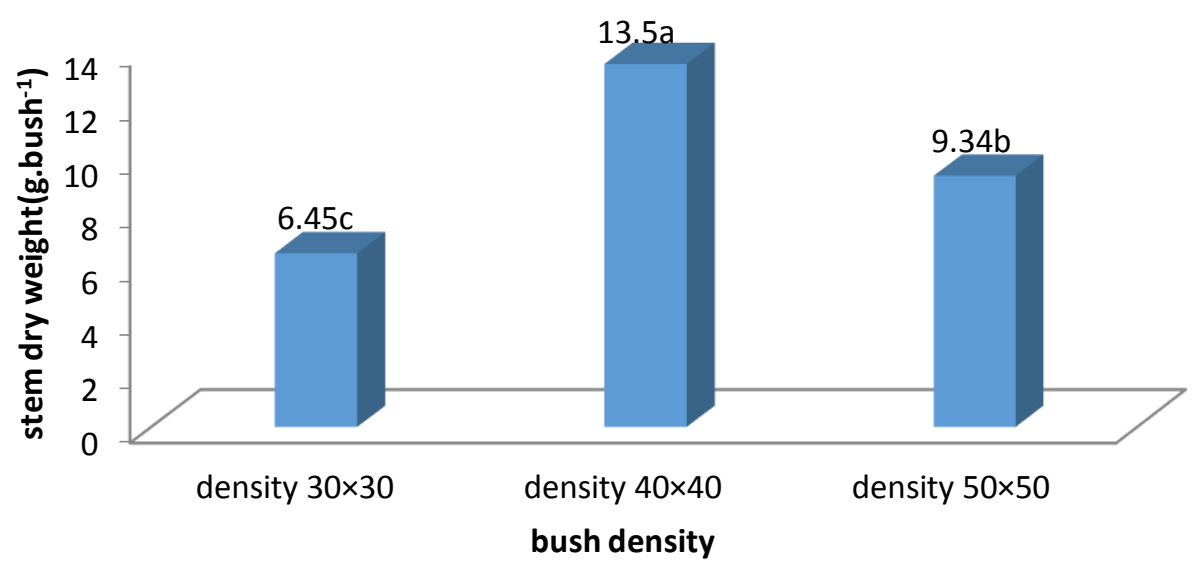

Diagram 25. Comparing the means of bush density on stem dry weight 


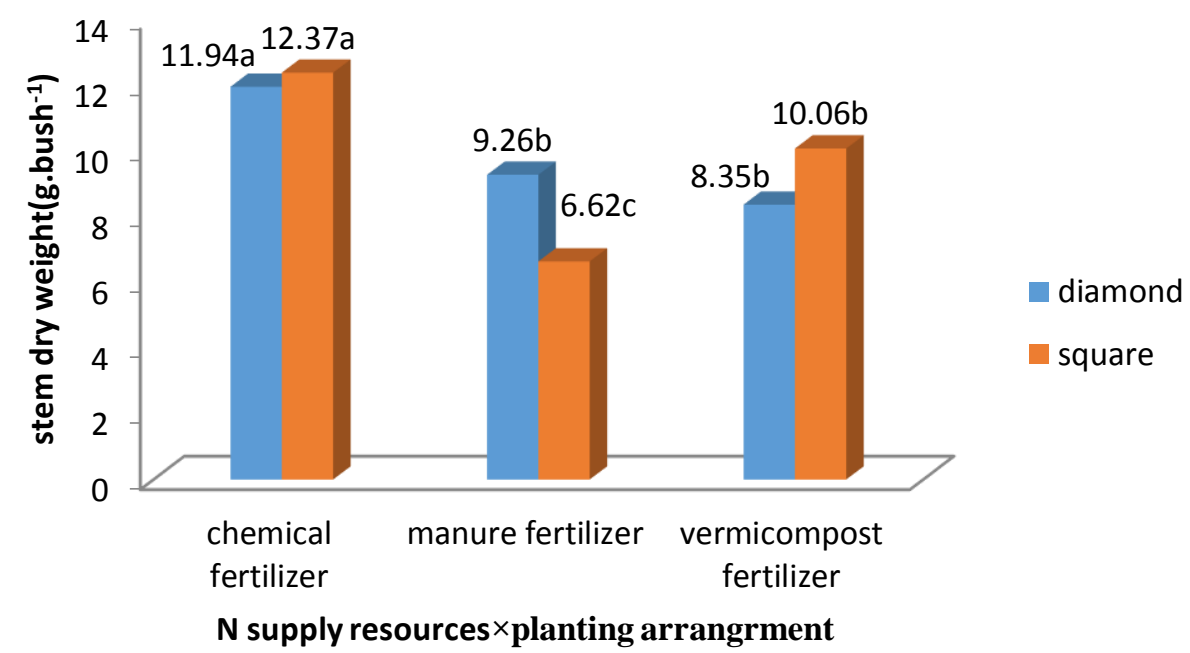

Diagram 26. Comparing the means of planting arrangement $\times$ nitrogen resources on stem dry weight

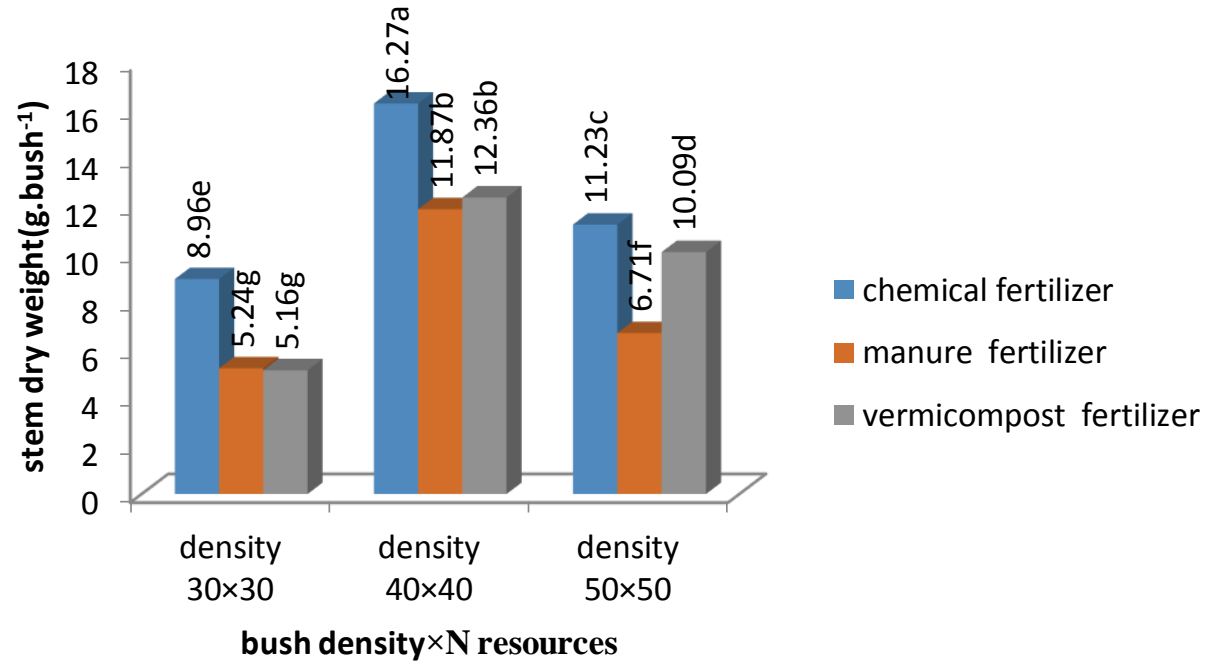

Diagram 27. Comparing the means of nitrogen resources $\times$ bush density on stem dry weight

\section{Conclusion}

The greatest number of leaves per bush for abstraction of essential oil was obtained from the following treatments: density of $40 \times 40 \mathrm{~cm}$, chemical fertilizer, square planting arrangement $\times$ chemical fertilizer, diamond planting arrangement $\times$ density of $40 \times 40 \mathrm{~cm}$, chemical fertilizer $\times 30 \times 30 \mathrm{~cm}$ density.

\section{References}

Emam, E, 2004. Agronomy-Cereals. Shiraz University Press. P 91.

Allahdadi E., G. A. Akbari and Z. Ghahrmani, 2003. Producing Vermicompost and SideProducts, Tehran University Press.

Omid Bigy, R. 2000. Production Approaches and Processing of Medicinal bushs. Designers Publication, The first volume. 
Dadvand, M., H. Naghdibadi M., Nasri M. Maleki Zadeh M. Omidi, 2008. Changes in the amount of oil and herbs of ocimum basilicum, under the influence of density and nitrogen fertilizer. Journal of Medicinal bushs. Vol 27. No 3: PP 60-70.

Zargari, A, 1990. Medical bushs. Tehran University Press.Vol2, P 923.

Mola Filabi A, H. Mouri M. H., Rashed Mohasel M. Kadi, 2009. The impact of bush density and nitrogen on the performance and yield components of black seed medicinal bush. Summary of the articles presented in the Medical bushs Industry Development Conference in Iran. P 194.

Vakili shahrbabaki, S. M, 2014. The effect of plant density and quantity of nitrogen fertilizer on vegetative function of lawsonia inermis L. in jiroft. 2 (1): 51-62.
Hossein poor, M., A. R. Pirzad., H. Habibi and M. H. Phootokian. 2011. Effect of biological nitrogen fertilizer (azotobacter) and plant density on yield, yield components and essential oil of anise. 21 (1): 69-88.

Saeed-Nejad, A. H. and P. Rezvani Moghadam, 2009. Evaluation the effect of using composting, vermicompoosting and manure on yield, yield components and essential oil cuminum cyminum. Journal of Horticultural Science. Vol. 24, No. 2, Fall-Winter 2010-2011, P. 142-148. ISSN: 2008-4730.

Scheffer, M. C and H. S. Koehler, 1993. Influence of organic fertilization on the biomass, yield and yield composition of the essential oil of Achillea millefolium. Acta Horticulture, 331: 109-114. 